\title{
Stanowisko Komitetu Zdrowia Publicznego Polskiej Akademii Nauk w sprawie szczepień przeciw COVID-19
}

\section{Komitet Zdrowia Publiczneyo Polskiej Akademii Nauk (KZP PAN)}

- Mając na uwadze historyczne i bieżące negatywne doświadczenia ludzkości związane z epidemiami, które $\mathrm{w}$ przeszłości i obecnie pochłonęły miliony istnień,

- Uznając prawo ludzi do życia w zdrowiu i komforcie, jaki daje zniesienie epidemicznych zakazów i nakazów,

- Występując w obronie prawa każdego do swobodnego poruszania się i komunikowania z najbliższymi, przyjaciółmi oraz spotkań grupowych,

- Uznając prawo do pracy, zdrowia, poczucia bezpieczeństwa zdrowotnego, w tym w sferze psychicznej, uczestniczenia w rozwoju społeczno-gospodarczym i kulturowym, a przede wszystkim szanując dorobek w obszarze biznesu, produkcji i dążenia każdego do poprawy bytu ekonomicznego oraz jakości życia, na które epidemie chorób zakaźnych wpływają destrukcyjnie,

- Uznając bezsprzecznie udowodnione naukowo pozytywne doświadczenia roli szczepień ochronnych $\mathrm{w}$ walce $\mathrm{z}$ epidemiami, a więc $\mathrm{w}$ trosce o dobro jednostki i zbiorowości,

- Doceniając naukowo potwierdzoną skuteczność zatwierdzonych oficjalnie szczepionek przeciw COVID-19, przy śladowym występowaniu skutków niepożądanych,

- Dysponując dowodami, że tylko odporność populacyjna, uzyskania dzięki zaszczepieniu dostatecznie dużego odsetka ludności umożliwia powrót do normalnego funkcjonowania,

- Wykorzystując dotychczasowe doświadczenia z przebiegu pandemii wskazujące kluczową rolę w jej zwalczaniu odgrywaną przez przedstawicieli zawodów medycznych oraz osoby zatrudnione $\mathrm{w}$ instytucjach opiekuńczych i wychowawczych,

\section{apeluje do Wtadz Rzeczypospolitej Polskiej o zainicjowanie i przeprowadzenie następujacych przedsięwzięc:}

- Wprowadzenie ustawowego obowiązku wszystkich osób zatrudnionych w instytucjach zaspokajających potrzeby zdrowotne, opiekuńcze i wychowawcze do przyjęcia szczepień przeciw tragicznej w skutkach i nadal rozwijającej się epidemii COVID-19.

- Wdrożenie szeroko zakreślonej akcji informacyjnej nakłaniającej do poddania się jak najliczniejszych grup społecznych, w tym grup szczególnie narażonych, jak seniorzy, ale także młodzieży i dzieci, mogących przyczyniać się do rozprzestrzeniania się wirusa oraz zintensyfikowania działań ułatwiających zaszczepienie dla osób, którym jest to potrzebne.

- Zachęcenie władz samorządu terytorialnego do wdrażania szerokiej gamy dostępnych bodźców i nagród zachęcających do szczepienia oraz do podjęcia współpracy $\mathrm{w}$ tej dziedzinie $\mathrm{z}$ organizacjami obywatelskimi.

Jednocześnie KZP PAN zwraca się do Samorządów Zawodów

Medycznych o jednoznacznie krytyczne występowanie w przypadkach publiczneyo kwestionowania zasadności szczepień przeciw COVID-19 przez ich członków.

Warszawa, 10 czerwca 2021 


\title{
UZASADNIENIE
}

\section{Włodzimierz Cezary Włodarczyk ${ }^{1}$ (1) https://orcid.org/0000-0001-9616-391x}

Grzegorz Juszczyk ${ }^{2}$ (1) https://orcid.org/0000-0002-6794-2786

Tomasz Zdrojewski ${ }^{3}$ (i) https://orid.org/0000-0001-6015-8561

Wojciech Hanke ${ }^{4}$ (D) https://orid.org/0000-0001-7162-2569

Bolesław Samoliński 5 (10 https:/orid.org/0000--0002-4043-7747

Bogdan Wojtyniak ${ }^{2}$ (i) https://orid.org/0000-0002-2135-8226

\author{
${ }^{1}$ Zakład Polityki Zdrowotnej i Zarządzania, Instytut Zdrowia Publicznego, Wydział Nauk o Zdrowiu Uniwersytet \\ Jagielloński Collegium Medicum \\ ${ }^{2}$ Narodowy Instytut Zdrowia Publicznego PZH - Państwowy Instytut Badawczy \\ ${ }^{3}$ Katedra Nadciśnienia Tętniczego i Diabetologii, Gdański Uniwersytet Medyczny \\ ${ }^{4}$ Zakład Epidemiologii Środowiskowej, Instytut Medycyny Pracy \\ ${ }^{5}$ Zakład Profilaktyki Zagrożeń Środowiskowych i Alergologii, Warszawski Uniwersytet Medyczny
}

\section{Abstract}

\section{The Resolution of Public Health Committee Polish Academy of Science on Vaccination against COVID-19}

Public health community worldwide encouraged by successes of former campaigns have always accepted vaccination as the most effective way to handle infectious diseases pandemics. Even before the outburst of SARS-CoV-2 pandemic in many countries mandatory vaccination against many diseases, especially child related had been implemented. From among 193 countries under study in as many as 105 (54\%) such obligation existed and in 62 of them (59\%) at least one form of punishment or harm for those opposing was involved. Following this sort of available solutions and facing COVID-19 pandemic disaster the authors on behalf of the Public Health Committee of the Polish Academy of Science recommend to the government implementation od mandatory vaccination against COVID-19 for all workers in sectors of health care, education and welfare.

\section{Key words: COVID-19, mandatory vaccination, pandemic, Polish Academy of Science, vaccination}

Stowa kluczowe: COVID-19, obowizzkowe szczepienia, pandemia, Polska Akademia Nauk, szczepienia

\section{Wprowadzenie. Korzyści ze szczepień}

Światowa społeczność zdrowia publicznego nie miała wątpliwości, że szczepionka skutecznie zapobiegająca zakażeniu wirusem SARS-CoV-2 jest jedyną efektywną metodą przeciwstawiania się pandemii, a udane w przeszłości kampanie masowych szczepień były argumentem uprawdopodobniającym tę tezę [1]. Kiedy w kwietniu 2020 roku przygotowano preferowane cechy przyszłego produktu, przyjęto, że jego skuteczność powinna osiągać poziom $70 \%$, ale także - w pewnych sytuacjach $50 \%$ mogło być uznane za zadowalające [2]. Kiedy więc po wynalezieniu szczepionki w charakterystykach poszczególnych szczepionek przedstawianych przez wytwórców w oznaczeniach skuteczności pojawiały się takie liczby jak 95-100\% (Pfizer/BioNTech), 76-79\% (Oxford/AstraZeneca), 94-100\% (Moderna) [3], perspektywy opanowania pandemii rysowały się znacznie bardziej optymistycznie.

Eksperci zdrowia publicznego zdawali sobie sprawę z korzyści powszechnych szczepień, ale ważne też były komunikaty przekazywane opinii publicznej. Późną wiosną 2021 roku na stronach Światowej Organizacji Zdrowia (WHO, World Health Organization) opublikowane zostały przeznaczone dla ogółu odbiorców informacje na temat korzyści wynikających ze stosowania szczepionek [4]. Wskazano tam, że najważniejszym pozytywnym efektem jest ochrona osób zaszczepionych przed zachorowaniem albo ciężkim i groźnym dla życia przebiegiem infekcji.

W informacji przedstawionej przez amerykański Centers for Disease Control and Prevention (CDC) na początku kwietnia 2021 roku, dotyczącej wstępnych wyników badań przeprowadzonych wśród pracowników służby zdrowia, skuteczność szczepionki oceniono na 90\% przy pełnym szczepieniu [5]. W komentarzu podkreślono, że problem skuteczności był analizowany w środowisku najbardziej narażonym na zakażenia, a więc uzyskane rezultaty powinny być w pełni docenione.

W komunikacie, w którym omówiono wyniki „największego badania" skuteczności szczepionki stosowanej $\mathrm{W}$ szczepieniu pracowników służby zdrowia, ogłoszonym w połowie maja 2021 roku przez tę samą instytucję, przedstawiono wielkość 94\% [6]. 
W przygotowanym przez Instytut Uniwersytetu Waszyngtona w Seattle i opublikowanym pod koniec maja 2021 roku podsumowaniu badań dotyczących skuteczności poszczególnych szczepionek w ciężkim przebiegu choroby (efficacy at preventing disease) wskazano wielkości od 72 do 94\% [7].

We wczesnych badaniach przeprowadzonych w Anglii skuteczność szczepionki Pfizer (dwie dawki) po 7 dniach została oceniona na $88 \%$, a w Szkocji podanie jednej dawki tej szczepionki było skuteczne w $85 \%$, podczas gdy szczepionka AstraZeneca była skuteczna w 94\% [8].

Stosując wskaźnik względnej redukcji ryzyka (relative risk reduction - RRR), autorzy raportu opublikowanego W „Lancecie” przedstawili następujące dane o skuteczności szczepionek: Pfizer/BioNTech - 95\%, Moderna-94\%, Johnson \& Johnson, AstraZeneca i Oxford - 67\% [9].

$\mathrm{Na}$ podstawie wyników kilku badań stwierdzono, że skuteczność szczepień w Izraelu przekraczała przeciętnie $90 \%$, w niektórych grupach wiekowych sięgając 96\% i więcej [10].

Bardzo zachęcające okazały się wyniki badań skuteczności szczepionek przeciwko nowym wariantom wirusa, co było informacją istotną wobec obaw dotyczących ich nieprzygotowania do aktywności wobec nieznanej struktury, zwłaszcza wariantu indyjskiego. Opublikowany w maju 2021 roku preprint artykułu omawiającego uzyskane wyniki rozwiewał te obawy [11]. Chiński portal informujący o tym wydarzeniu napisał o $88 \%$ skuteczności szczepionki Pfizer i 60\% szczepionki AstraZeneca w stosunku do indyjskiego wirusa, pod warunkiem jednak pełnego, dwudawkowego szczepienia [12].

W połowie kwietnia 2021 roku na stronach CDC ukazał się komunikat, w którym szczepionki przeciw COVID-19 stosowane w USA zostały określone jako skuteczny i bezpieczny środek chroniący przed zakażeniem się wirusem [13]. Wprawdzie może się zdarzyć, że mimo szczepienia dojdzie do infekcji, ale przebieg choroby jest wówczas łagodny i bez poważniejszych następstw. W ogólnej ocenie stwierdzono, że mimo ujawniających się niekiedy niekorzystnych reakcji na sam fakt podania szczepionki w ogólnym bilansie akcja szczepienia przynosi nieporównanie więcej korzyści niż konsekwencji odczuwanych jako straty ${ }^{1}$.

Przykładem rzetelnego i odpowiedzialnego sposobu komunikowania się ze społeczeństwem była informacja przedstawiona przez portal Healthline [15]. Zaakcentowano wyraźnie, że zatwierdzone do stosowania szczepionki przeciw COVID-19 są „,bardzo skuteczne”, choć oczywiście nie w 100\% i osoby poddane szczepieniu muszą sobie zdawać $\mathrm{z}$ tego sprawę. O szczepionkach Moderna i Pfizer napisano, że po pierwszej dawce zapobiegają w $80 \%$ zakażeniu objawowym przebiegiem infekcji (po 14 dniach), a po drugiej dawce skuteczność rośnie do 90\%. Szczepionka Johnson \& Johnson zapobiegała infekcji w 66\%, ale w 100\% zapobiegała ciężkiemu przebiegowi choroby. Przypomniano też, że skuteczność rutynowo wykorzystywanej szczepionki przeciwko grypie wynosi 19-60\%.

Niekiedy opis potencjalnych korzyści był przedstawiany w postaci argumentów adresowanych do pacjentów korzystających z opieki zdrowotnej, jak to uczyniono na stronie Health Care Uniwersytetu Missouri [16]. Zamieszczono tam listę argumentów przemawiających za zaszczepieniem: zmniejszenie ryzyka infekcji; ochrona płodu i noworodka, kiedy ciężarna jest zaszczepiona; ochrona przed ciężkim przebiegiem infekcji i ewentualnymi powikłaniami; znoszenie ograniczeń, takich jak obowiązek noszenia maseczek, dzięki uzyskaniu odporności; a także na odnowienie bliskich kontaktów ze znajomymi i przyjaciółmi.

W światowych mediach popularyzujących zdrowy styl życia zwrócono uwagę na korzyści niezamierzone bezpośrednio, ale będące pozytywnym następstwem szczepień [17]. Poza spodziewanym zmniejszeniem liczby zachorowań spowodowanych klasycznym wariantem SARS-CoV-2 stosowane szczepionki chronią także przeciw jego powstającym z mutacji wariantom: brytyjskim, brazylijskim czy południowoafrykańskim. Jeśli doszło do infekcji, późniejsze szczepienie pozwalało osłabić długotrwałe, utrzymujące się po pozornym wyleczeniu skutki infekcji. Bardzo korzystne było dostrzegalne zmniejszenie się intensywności odczuwanego lęku, co ułatwiało przezwyciężanie psychologicznych skutków pandemii.

\section{Postawy i głosy sceptyczne}

Mimo oczywistości racjonalnych argumentów przemawiających za koniecznością szczepienia się postawy wobec problemu były bardziej krytyczne. W Zjednoczonym Królestwie 71,7\% populacji deklarowało gotowość zaszczepienia się, 16,6\% wyrażało pewne wahanie, ale u $11,7 \%$ było ono bardzo silne [18]. Wśród włoskich pracowników służby zdrowia $67 \%$ deklarowało zamiar poddania się szczepieniom, 26\% miało pewne wątpliwości co do swojej decyzji, a 7\% odmawiało szczepienia się [19]. Niechęć do szczepienia może stać się problemem w wielu krajach. Z zestawienia opublikowanego pod koniec kwietnia 2021 roku wynikało, że we Francji odsetek wahających się obywateli sięgał $48 \%$, z tego $34 \%$ zdecydowanie odmawiało zaszczepienia [20]. W Korei Południowej był ten sam odsetek wahających się, ale odsetek zdecydowanych przeciwników był niższy i wynosił $22 \%$, a w USA odpowiednio prawie $37 \%$ i $28 \%$. W Polsce w badaniu IBRiS przeprowadzonym w kwietniu 2021 roku dla „Rzeczpospolitej” 60\% odpowiadających deklarowało gotowość zaszczepienia się, w badaniach lutowych w grupie tej było $64 \%$ badanych [21]. W nowszych badaniach było $20 \%$ osób odmawiających szczepienia, poprzednio było ich $62 \%$. $\mathrm{W}$ badaniach przeprowadzonych $\mathrm{w}$ grudniu 2020 roku przez tę samą firmę zwolennicy szczepień mieli niewielką przewagę w stosunku $47 \%$ do $44 \%$ [22]. Nie dysponujemy wynikami badań na temat stanowiska polskich lekarzy wobec szczepień, ale mamy nadzieję, że treści przedstawione w „Apelu naukowców i lekarzy w sprawie szczepień na koronawirusa SARS-CoV-2" nie są dla nich reprezentatywne [23]. Apel rozpoczyna się sformułowaniem następującym: „Środowisko naukowców i lekarzy, jakie reprezentują osoby podpisane pod tym apelem, pragnie wyrazić zaniepokojenie perspektywą 
masowych szczepień na koronawirusa SARS-CoV-2 szczepionkami, które nie zostały właściwie zbadane i których zastosowanie może doprowadzić do nieoczekiwanych zmian zarówno na poziomie komórkowym, w tym zmian szlaków sygnałowych i zmiany ekspresji genów". Powstrzymamy się od komentowania naukowej wartości zawartych w Apelu treści, nie można jednak uniknąć uwagi i jego szkodliwości z punktu widzenia zdrowotnych interesów obywateli, namawianych do unikania zachowań racjonalnych. Stąd oczekiwać można, że spotka się on z jednoznacznie krytyczną reakcją ze strony samorządów zawodów medycznych.

\section{Stanowisko agencji akredytujacych szczepionki}

Jeszcze na długo przed ukończeniem prac zmierzających do wyprodukowania szczepionek przeciwko COVID-19 Food and Drug Administration (FDA), amerykańska instytucja odpowiedzialna za decyzję o dopuszczeniu leku do stosowania, zadeklarowała, że bezpieczeństwo pacjentów i skuteczność szczepionki będą podstawowymi kryteriami oceny analizowanych preparatów [24]. Agencja potwierdziła, że jej aprobująca decyzja jest jednoznaczna z potwierdzeniem zdrowotnych korzyści dla osób zaszczepionych, będąc również gwarancją pełnego bezpieczeństwa. W podjętej 11 grudnia 2020 roku decyzji dopuszczającej stosowanie szczepionki firmy Pfizer/ BioNTech stwierdzono, że jest ona skuteczna w zapobieganiu chorobie COVID-19, początkowo dla dorosłych, a następnie dla dzieci od 12. roku życia [25]. Analogiczna argumentacja została przedstawiona na temat tej samej szczepionki przez Europejską Agencję ds. Leków (European Medicines Agency - EMA), w decyzji z 21 grudnia 2020 roku, rekomendując jej stosowanie wobec pacjentów powyżej 16. roku życia [26]. Dla zilustrowania sposobu rozumowania oficjalnych instytucji oceniających działanie szczepionek warto przytoczyć stanowisko EMA w sprawie obaw dotyczących ubocznych skutków szczepionki Oxford/AstraZeneca. Reagując na rozpowszechniane w różnych mediach informacje o przypadkach wystąpienia po szczepieniu zakrzepów krwi, a nawet spowodowanych tym zgonów i zawieszeniu przez kilka europejskich rządów stosowania tego preparatu, EMA odbyła nadzwyczajne posiedzenie w tej sprawie i opublikowała komunikat. Napisano w nim, że szczepionki pozostają najbardziej skuteczną metodą walki z wirusem, oceniany preparat jest jedną z nich, a korzyści wynikające z poddania się szczepieniu wielokrotnie przewyższają ryzyko skutków ubocznych [27]. Dalej przytoczono dane zebrane do 16 marca 2021 roku, z których wynikało, że na około $20 \mathrm{mln}$ zaszczepionych tym preparatem osób, zdarzyło się 7 zakrzepów krwi w naczyniach krwionośnych (disseminated intravascular coagulation - DIC) i 18 przypadków zatorów w naczyniach mózgowych (cerebral venous sinus thrombosis CVST). Nie potwierdzono przy tym żadnej zależności przyczynowej między faktem zaszczepienia i wystąpieniem działań niepożądanych, które mogły być wywołane zupełnie innymi czynnikami. W tej sytuacji pozytywna opinia EMA wydawała się oczywista.

\section{Odporność populacyjna}

Szczepionka chroni osoby zaszczepione przed infekcją, ale ważnym i ze wszech miar pożądanym efektem, do którego powinny prowadzić masowe szczepienia, jest uzyskanie stanu odporności stadnej (herd immunity) czy populacyjnej. Jest to sytuacja, w której wirus traci możliwości rozprzestrzeniania się w populacji, która uzyskała odporność już to $\mathrm{w}$ rezultacie przechorowania przez dostatecznie duży segment grupy, już to w efekcie jego zaszczepienia [28]. Oczywiście w społecznej rzeczywistości możliwe jest sumowanie się skutków obydwu źródeł odporności, ale trudno, aby rozwiązanie takie było zalecane jako opcja polityki zdrowotnej, a Dyrektor Generalny WHO wypowiedział się zdecydowanie przeciwko traktowaniu odporności zbiorowej uzyskiwanej drogą masowych zachorowań jako zalecanej metody walki z pandemią [29]. Metoda powszechnych szczepień pozostaje więc jedyną metodą walki z pandemią.

Pozostaje sprawą sporną, jak duży powinien być zaszczepiony odsetek zbiorowości umożliwiający stan populacyjnej odporności. Eksperci z USA szacowali go w granicach 60-90\% [30]. Profesor Suzanne Judd ze Szkoły Zdrowia Publicznego Uniwersytetu Alabamy w Birmingham wskazywała przykład Izraela, który osiągnął ten stan przy poziomie wyszczepienia równym $80 \%$ [31]. Profesor Maciej Banach wskazał wielkość 60\% [32]. Wielkości te, także bez rozstrzygania co do szczegółów, wyznaczały pożądany kierunek działań w zwalczaniu pandemii - należało dążyć do zaszczepienia możliwie największego odsetka chronionej społeczności.

\section{Szczepienia jako obowiązek}

W opublikowanych niedawno wynikach badań stwierdzono, że spośród 193 analizowanych krajów w 105 (54\%) istniał jakoś sformułowany obowiązek poddania się szczepieniu [33]. Wśród tych krajów w 62 (59\% stosujących obowiązek szczepienia) wymieniona była przynajmniej jedna kara (dolegliwość) stosowana wobec osób nieprzestrzegających obowiązku. Kary te - niekiedy stosowano tylko niektóre spośród nich - różniły się znacznie co do stopnia surowości i procedur orzekania o ich zastosowaniu. Ich zestaw jest przedstawiony w tabeli 1 .

Tabela 1. Kary za nieprzestrzeganie obowiązku szczepień

\begin{tabular}{|l|l|}
\hline \multicolumn{2}{|c|}{ Rodzaje kar } \\
\hline Pieniężne & $\begin{array}{l}\text { Grzywna jednorazowa } \\
\text { Grzywna wielokrotna }\end{array}$ \\
\hline Dotyczące opieki rodzicielskiej & $\begin{array}{l}\text { Czasowe pozbawienie praw } \\
\text { Długotrwałe pozbawienie praw }\end{array}$ \\
\hline $\begin{array}{l}\text { Związane z systemem } \\
\text { szkolnym }\end{array}$ & $\begin{array}{l}\text { Wpis do dokumentacji szkolnej } \\
\text { Czasowe zawieszenie prawa } \\
\text { wstępu do szkoły } \\
\text { Odmowa przyjęcia do szkoły }\end{array}$ \\
\hline Ograniczenia wolności & $\begin{array}{l}\text { Kara więzienia z zawieszeniem } \\
\text { Kara bezwzględnego więzienia }\end{array}$ \\
\hline
\end{tabular}

Źródto: [33]. 
Z uwagi na czas badania przedstawiony w wynikach obowiązek szczepienia nie dotyczył w żadnej mierze COVID-19 i obejmował szczepienia w tradycyjnym zakresie. Niemniej przedstawiony obraz może być przydatny w rozważaniu obowiązku szczepień przeciw tej chorobie.

Alternatywą dla przymusu szczepień, związanego z systemem sankcji, jest podejście polegające na stosowaniu bodźców pozytywnych. Metody takie zostały zaproponowane w wielu krajach, także w USA [34]. Gubernator stanu Ohio zarekomendował wprowadzenie specjalnej loterii dla osób korzystających ze szczepień, której zwycięzca miał szanse wygrać kwotę miliona dolarów. Młodzi obywatele Wirginii Zachodniej byli zachęcani bonem o wartości 100 \$, a Uniwersytet Karoliny Północnej refundował szczepiącym się studentom koszty zakwaterowania. Repertuar korzyści oferowanych osobom zaszczepionym był bardzo szeroki i część z nich dotyczyła spraw banalnych, jak jedzenie: darmowe porcje pizzy, owoce morza, burgery i cheeseburgery, desery, pączki, bezalkoholowe piwo dla nieletnich i alkoholowe dla dorosłych [35]. Przedstawiane były pomysły wprowadzenia „karty osoby zaszczepionej”, podobnej do kart turystycznych dostępnych w wielu atrakcyjnych miastach, które dawałyby uprawnienia do darmowego albo ulgowego wstępu do atrakcyjnych obiektów i bezpłatnego korzystania z komunikacji miejskiej [36].

W wielu sytuacjach bodźce takie okazywały się skuteczne, ale jednocześnie wywoływały wątpliwości natury etycznej, czy wynagradzanie zachowań ze wszech miar korzystnych dla beneficjentów powinny być dodatkowo gratyfikowane finansowo. Ponadto nie było jasne, jakie ma być źródło wydawanych na ten cel pieniędzy.

Proponując poważne rozważenie przez środowisko zdrowia publicznego postulatu wprowadzenia przymusu poddawania się szczepieniom przeciw COVID-19, jesteśmy świadomi pełnego rezerwy stanowiska WHO w tej kwestii [37]. Zdajemy sobie także sprawę, że termin przedstawienia stanowiska przez tę instytucję - połowa kwietnia 2021 roku - świadczy o przeprowadzeniu starannego namysłu, co chroni autorów przed zarzutem zaprezentowania pochopnej i szybkiej decyzji. Niechęć wobec przymusu szczepień jest w dokumencie widoczna, mimo zastrzeżenia, że autorzy nie przedstawiają jednoznacznej deklaracji za lub przeciw szczepieniom, ale tekst ma także warstwę perswazyjną, która polega na użyciu w tytule nie tylko słowa odnoszącego się do skrupulatnego namysłu (consideration), ale także do przeszkód czy zastrzeżeń etycznej natury (caveats), jakie procedura szczepień może wzbudzać.

Autorzy wyjaśniają, że „obowiązek szczepienia” jest procedurą stosowaną przez upoważnione organy państwa mającą na celu zaszczepienie możliwie dużej liczby populacji, wobec której obowiązek jest wprowadzany. Mowa jest o dużej liczbie czy odsetku populacji, ponieważ osiągnięcie pełnego, stuprocentowego wyszczepienia nie jest praktycznie możliwe, bo zawsze występują jakieś istotne przeszkody - jak uczulenie - które uniemożliwiają zastosowanie szczepionki. Obowiązek szczepienia może dotyczyć całej populacji, ale zwykle jest adresowany do wyraźnie wskazanej grupy, jak obowiązek szczepienia dzieci przeciwko wskazanym chorobom, co jest regułą w wielu krajach. Pierwszym niezbędnym krokiem przy wprowadzaniu obowiązku szczepienia jest przyjęcie odpowiedniego przepisu, co powinno następować zgodnie z prawem kraju, w którym operacja ta jest przeprowadzana. Jednak samo ustanowienie normy nakazującej szczepienie nie jest wystarczające, gdyż nie kończy stosowania procedury, a jedynie je rozpoczyna. Jej istotą jest bowiem zestaw konsekwencji, w tym sankcji, które mogą być zastosowane wobec osób niepodporządkowujących się obowiązkowi szczepienia. Tylko wyjątkowo stosowany jest fizyczny przymus szczepienia, a zwykle fakt jego braku pociąga za sobą różnego rodzaju dolegliwości. Autorzy wskazali możliwość wyłączenia z możliwości korzystania z niektórych instytucji edukacyjnych i opiekuńczych, wykonywania niektórych zawodów i pracy na wskazanych stanowiskach, ale jednocześnie przypomnieli, że WHO nie rekomendowała stosowania takich restrykcji w transporcie międzynarodowym [38]. Obecność tego rodzaju sankcji, wskazanych w obowiązującym przepisie, różni formalny obowiązek szczepień od obligacji wywodzonej z reguł etycznych, w których występuje wskazanie wartości postępowania zgodnego z normami etycznymi, jak poczucie społecznej solidarności.

\section{Ewentualny konflilikt $z$ wartościami}

Ewentualne wprowadzenie obowiązku poddania się szczepieniom stoi $\mathrm{w}$ oczywistym konflikcie $\mathrm{z}$ obowiązującymi w demokratycznych krajach gwarancjami swobody i wolności osobistej ${ }^{2}$. Z tego powodu władza podejmująca rozważania na temat możliwości posłużenia się przymusem szczepienia powinna zadbać o dwie sprawy. Po pierwsze, posłużyć się odpowiednim środkiem prawnym tak, aby uniemożliwić ewentualne zakwestionowanie legalności podjętej decyzji na gruncie prawnym. Po drugie, wyważyć niezbędność i proporcjonalność stosowanej metody $\mathrm{w}$ porównaniu $\mathrm{z}$ wielkością zagrożenia mogącego powstać, jeśli dostatecznie radykalne środki nie zostaną podjęte.

Skomentujmy, że niezbędność wydaje się nie do podważenia, biorąc pod uwagę, że szczepionka jest jedyną dostępną metodą mogącą uchronić ofiarę przed zakażeniem lub ciężkim przebiegiem infekcji. Ocena proporcjonalności zależy od wartości przypisywanej potencjalnym stratom życia i zdrowia, które mogą być poniesione, jeśli odsetek zaszczepionych nie będzie wystarczająco duży. Dalej autorzy dokumentu [38] wskazują elementy sytuacji, które w minimalnym stopniu, albo wcale, nie zależą od krajowego systemu zdrowia publicznego. I tak przypominają zasadę bezpieczeństwa, co nie wydaje się należeć do kompetencji ani zdrowia publicznego ani decydentów, gwarancja bezpieczeństwa jest bowiem powiązana $\mathrm{z}$ decyzją instytucji odpowiadającej za dopuszczenie szczepionki do obrotu i stosowania. Kolejne kryterium dotyczy skuteczności i ekonomiczności szczepionki i procedury szczepienia. Dane na temat skuteczności szczepionki są pierwszą 
informacją przedstawianą przez producenta w procesie jej autoryzacji i są powszechnie dostępne, natomiast ekonomiczność, czyli ocenianie relacji zdrowotnych i innych korzyści do wydatków i strat ponoszonych w wyniku zaniechania szczepienia są przedmiotem bardzo skomplikowanej kalkulacji, która daleko wykracza poza kompetencje zdrowia publicznego.

Niewątpliwie bardzo ważny czynnik, wskazany jako ostatni - zaufanie społeczeństwa - to także parametr tylko częściowo i w niewielkim stopniu zależny od zdrowia publicznego. Wprawdzie eksperci z tej dziedziny w niektórych krajach mieli bardzo duży wpływ na podejmowane decyzje - w Szwecji wręcz wyłączny - to jednak w większości przypadków decyzje były podejmowane głównie przez polityków. Jeśli ich postępowanie osłabiało społeczne zaufanie, to działo się to na ogół albo z powodu pomijania wskazań ekspertów, albo wskutek jawnie instrumentalnego nadużywania argumentacji odwołującej się do pandemii do całkowicie innych, politycznie doraźnych interesów. Wzięcie pod uwagę i próby wyważania znaczenia poszczególnych elementów sytuacji musi być ostatecznie wpisane we wnikliwie prowadzony proces decyzyjny, w którym świadomie wykorzystywane są także racje i argumenty etyczne. Podkreślić jednak należy, że wymóg taki, czy raczej zalecenie, by był stosowany, dotyczy wszystkich decyzji, których efektem jest ograniczanie obywatelskich i ludzkich wolności. Zakazy społecznych kontaktów, mobilności przestrzennej i dotyczące różnych dziedzin lockdowny są tego jednoznacznym przykładem. Warto ze wszech miar podkreślić rolę czynnika, jakim jest pewność dostaw i gwarancja dotrzymywania ich terminów. W oczywisty sposób nie jest on zależny od zdrowia publicznego. W obecnych realiach zdolność terminowego wytwarzania szczepionek w wystarczających ilościach jest efektem niezwykleskomplikowanego konglomeratu bardzo zróżnicowanych czynników, zależnych nie tylko od uwarunkowań lokalnych, ale często wpisanych w ramy międzynarodowej współpracy, jak to ma miejsce w krajach Unii Europejskiej [40]. W świecie Zachodu tylko nieliczne kraje, poza USA, zdecydowały się na samodzielne postępowanie $\mathrm{w}$ tej dziedzinie, a wszystkie pozostałe negocjowały dostawy w ramach dużego bloku. Konieczność międzynarodowego współdziałania była oczywista, szczególnie, że pandemia doprowadziła do przerwania produkcyjnych łańcuchów współpracy. Ujawnione wówczas uzależnienie wielu krajowych producentów farmaceutycznych od chińskich dostaw poszczególnych komponentów leków wyraźnie to pokazało. Niezależnie jednak od wszelkich faktycznych uwarunkowań produkowania i dostarczania szczepionek z punktu widzenia racjonalności decyzji o wprowadzeniu obowiązku szczepień pewność dostaw jest warunkiem koniecznym. Żaden rząd nie może pozwolić sobie na kompromitację polegającą na wprowadzeniu obowiązku szczepienia bez zagwarantowania dostępności szczepionek. Jako otwarte należy pozostawić pytanie, czy takie gwarancje są możliwe w warunkach samowystarczalności krajowego przemysłu farmaceutycznego, czy też istnieją obecnie międzynarodowe struktury mogące je zapewnić.

\section{Wprowatzenie obowiazku jako opcja}

Przypadek sprawił, że w czasie, kiedy przed decydentami stanął problem ewentualnego wprowadzenia obowiązku szczepień przeciwko COVID-19, Europejski Trybunał Praw Człowieka (European Court of Human Rights - ECHR) wydał werdykt w sprawie wniesionej przez grupę czeskich rodziców protestujących przeciwko obowiązkowi szczepień ich dzieci [41]. Przedmiotem sporu była odmowa przyjęcia dzieci niezaszczepionych klasycznym zestawem szczepionek przeciwko 9 chorobom, a w argumentacji wskazywano, że przymus jest pogwałceniem prawa do prywatności. Trybunał w składzie 17 sędziów orzekł, że władze w demokratycznym państwie są uprawnione do nakładania takich obowiązków i nie jest to naruszenie granic prywatności. Zauważmy, że obowiązek ten dotyczył wszystkich dzieci, a więc całej, bardzo dużej części populacji. W jednym z komentarzy po orzeczeniu stwierdzono, że decyzja sądu może być postrzegana jako prawdopodobne otwarcie drogi do wprowadzenia analogicznego obowiązku szczepień przeciwko COVID-19 [42].

W wywiadzie przeprowadzonym w Szkole Zdrowia Publicznego na Uniwersytecie Harvarda na pytanie o możliwość wprowadzenia przymusu szczepień padła odpowiedź twierdząca [43]. Odpowiedź została udzielona przez ekspertkę, która nie miała wątpliwości, że władze stanowe i władze federalne mają ku temu niezbędne prawne i wynikające z Konstytucji uprawnienia, a racją decyzji jest obowiązek troski o zdrowie ogółu populacji. Ekspertka powołała się na orzeczenie Sądu Najwyższego z 1905 roku Chodziło o epidemię ospy, która wybuchła w stanie Massachusetts trzy lata wcześniej, a władze wprowadziły obowiązek szczepienia wszystkich mieszkańców. Niepoddanie się szczepieniu zostało zagrożone grzywną w wysokości 5 \$.

\section{Pierwsze doświadczenia}

$\mathrm{Na}$ terytorium Anglii i Walii (National Health Service Zjednoczonego Królestwa jest zdecentralizowany) przedmiotem uwagi był sposób ochrony pracowników służby zdrowia, znajdujących się na pierwszej linii walki z pandemią. Przez długi czas obowiązywała reguła, że ta grupa pracowników powinna mieć priorytetowy dostęp do szczepień, ale władze nie wprowadzały obowiązku zaszczepienia, a nawet złożyły deklarację, że takiego nie przewidują [44]. Jednak wahania części personelu medycznego co do zasadności poddania się szczepieniu sprawiły, że problem powrócił. Nastąpiło to przy pełnej świadomości, że przeciwnicy przymusu będą powoływać się na art. 8 Konwencji Praw Człowieka [45].

Zastrzeżeń i wątpliwości nie mieli dwaj eksperci związani z Uniwersytetem Oksfordzkim oraz Public Health England, którzy porównali obowiązek szczepienia przeciw COVID-19 do obowiązku stosowania pasów bezpieczeństwa w samochodach [46]. Można przypomnieć, że kilkadziesiąt lat temu, kiedy wprowadzano pasy, ich przeciwnicy także powoływali się na argument obrony wolności i prawo 
do samodzielnego podejmowania decyzji. Jednak praktyka dowiodła, że przymus w tej dziedzinie przyniósł korzyści w wymiarze społecznym, a ograniczenia swobód były minimalne. Jeśli nawet można zawahać się przed wprowadzeniem obowiązku szczepienia dla wszystkich, to nie ma wątpliwości, że powinien on objąć grupy szczególnie narażone i ważne dla funkcjonowania społeczeństwa.

Podobnie jednoznaczne stanowisko zajął przedstawiciel zdrowia publicznego z Nowej Zelandii, a więc jednego z tych krajów, które bardzo skutecznie radziły sobie z pandemią. Wskazał on grupę ponad 160 tys. pracowników służby zdrowia, wobec której obowiązek taki powinien być wprowadzony [47]. Przypomniał, że jest to grupa najbardziej narażona na infekcje i uznał za błąd sytuację, w której władze unikają deklaracji do jakiego pułapu wyszczepienia tej grupy pracowników należy dążyć.

Rozważany w różnych krajach obowiązek szczepienia wszystkich pracowników służby zdrowia stał się faktem we Włoszech, które wprowadziły go, począwszy od 1 kwietnia 2021 roku [48]. W ten sposób kraj, który jako pierwszy stał się ofiarą pandemii, był też pierwszy we wprowadzeniu tego obowiązku. Ważną rolę odegrały postawy części personelu, którzy deklarowali rezerwę wobec idei szczepień i wpisywali się na odpowiednie listy. W Lombardii na północy kraju było takich osób 6-10\%, a w Apulii na południu 10-15\%.

$$
* * *
$$

Biorąc pod uwagę stosunkowo duży odsetek osób w polskiej populacji deklarujących niechęć do zaszczepienia się i brak - jak dotychczas - skutecznej kampanii wspierającej szczepienia, uważamy, że środowisko zdrowia publicznego powinno przyjąć obowiązek szczepienia i dążyć do wprowadzenia go w życie. Powinien być to obowiązek powszechny, przy obniżanej stopniowo dolnej granicy wiekowej. Można jednak także rozważać, zwłaszcza w okresie początkowym, jego zawężenie do niektórych tylko grup ludności czy grup pracowniczych, jak pracownicy służby zdrowia, wszyscy pracownicy oświaty, opiekunowie osób starszych czy pracownicy handlu ${ }^{3}$. Realizm każe jednak pamiętać o warunku: dostawy szczepionek muszą być zagwarantowane. Podkreślić przy tym należy, że obowiązek szczepienia nie jest równoznaczny z rezygnacją ze stosowania bodźców będących gratyfikacją dla osób zaszczepionych. Wszystkie inicjatywy zwiększające prawdopodobieństwo podjęcia dobrowolnie decyzji o poddaniu się szczepieniu powinny być wspierane $\mathrm{w}$ ramach obowiązującego prawa i to niezależnie od tego, kto byłby ich autorem. Długofalowy, wspólny, bo narodowy interes zdrowotny, będący też warunkiem normalnego funkcjonowania zbiorowości, powinien skutecznie eliminować doraźne gry polityczne. Byłoby ze wszech miar pożądane, aby możliwie powszechna stała się świadomość oczywistych korzyści płynących ze szczepień - korzyści dla samych zaszczepionych, dla ich bliskich, ale także dla społeczności i całego społeczeństwa.

\section{Przypisy}

${ }^{1}$ Szukając argumentów podnoszonych przez kręgi antyszczepionkowców, że szczepienie nie zapobiega w 100\% infekcji, już po opracowaniu tekstu Uzasadnienia autorzy znaleźli dotychczas zebrane dane na temat akcji szczepień w USA i jej skutków [14]. W okresie od początku akcji szczepień do 12 lipca 2021 roku przeciwko COVID-19 w pełni zaszczepionych zostało ponad 159 mln ludzi. Spośród zaszczepionych w stosunku 1 do 5189 konieczna okazała się hospitalizacja z powodu pogorszenia się stanu zdrowia. Jednak w tej liczbie 1456 (28\%) osób byli to pacjenci bezobjawowi lub cierpiący na schorzenie niezwiązane z COVID-19. W tym samym czasie w grupie w pełni zaszczepionych doszło do 1063 zgonów; spośród nich 272 śmierci były przypadkami bezobjawowymi lub niezwiązanymi z COVID-19.

${ }^{2}$ Art. 8 pkt 2. Niedopuszczalna jest ingerencja władzy publicznej w korzystanie $\mathrm{z}$ tego prawa $\mathrm{z}$ wyjątkiem przypadków przewidzianych przez ustawę i koniecznych w demokratycznym społeczeństwie $\mathrm{z}$ uwagi na bezpieczeństwo państwowe, bezpieczeństwo publiczne lub dobrobyt gospodarczy kraju, ochronę porządku i zapobieganie przestępstwom, ochronę zdrowia i moralności lub ochronę praw i wolności osób [39].

${ }^{3} \mathrm{~W}$ literaturze stosowany jest termin essential workers [49].

\section{Piśmiennictwo}

1. World Health Organization, The Vaccines Success Story Gives Us Hope for the Future, July 14, 2020, https://www. who.int/news-room/feature-stories/detail/the-vaccines-success-story-gives-us-hope-for-the-future (dostęp: 7.06.2021).

2. World Health Organization, Target Product Profiles for COVID-19 Vaccines, April 29, 2020,

3. https://cdn.who.int/media/docs/default-source/blue-print/ who-target-product-profiles-for-covid-19-vaccines.pdf?sfvrsn=1d5da7ca_5 (dostęp: 7.06.2021).

4. Detmer W.M., Coronavirus COVID-19 Vaccines, Unbound Medicine, May 11, 2021, https://relief.unboundmedicine. com/relief/view/Coronavirus-Guidelines/2355056/all/ Coronavirus_COVID_19_Vaccines (dostęp: 5.06.2021).

5. World Health Organization, COVID-19 Advice for the Public: Getting Vaccinated, 2021, https://www.who.int/emergencies/diseases/novel-coronavirus-2019/covid-19-vaccines/advice (dostęp: 2.06.2021).

6. Centers for Disease Control and Prevention, Interim Estimates of Vaccine Effectiveness of BNT162b2 and mRNA-1273 COVID-19 Vaccines in Preventing SARSCoV-2 Infection Among Health Care Personnel, First Responders, and Other Essential and Frontline Workers - Eight U.S. Locations, December 2020-March 2021, April 2, 2021, https://www.cdc.gov/mmwr/volumes/70/wr/ mm7013e3.htm?s_cid=mm7013e3_w (dostęp: 2.07.2021).

7. Centers for Disease Control and Prevention, Largest CDC COVID-19 Vaccine Effectiveness Study in Health Workers Shows mRNA Vaccines 94\% Effective, May 14, 2021, https:// www.cdc.gov/media/releases/2021/p0514-covid-19-vaccine-effectiveness.html (dostęp: 8.06.2021).

8. Institute for Health Metrics and Evaluation, COVID-19 Vaccine Efficacy Summary, May 21, 2021, http://www. healthdata.org/covid/covid-19-vaccine-efficacy-summary (dostęp: 3.06.2021). 
9. Clinch M., Ellyatt H., 4 Charts Show how the UK's Coronavirus Vaccine Rollout is Starting to Work, CNBC, March 3, 2021, https://www.cnbc.com/2021/03/01/coronavirus-uk-charts-show-how-vaccines-are-working.html (dostęp: 4.06.2021).

10. Olliaro P. et al., COVID-19 Vaccine Efficacy and Effectiveness - the Elephant (Not) in the Room, „The Lancet”, April 20, 2021, https://www.thelancet.com/journals/lanmic/article/PIIS2666-5247(21)00069-0/fulltext (dostęp: 7.06.2021).

11. Van Beusekom M., Real-World Studies Detail High Pfizer COVID Vaccine Protection, Center for Infectious Disease Research and Policy, University of Minnesota, May 7, 2021, https://www.cidrap.umn.edu/news-perspective/2021/05/real-world-studies-detail-high-pfizer-covid-vaccine-protection (dostęp: 5.06.2021).

12. Bernal J.L. et al., Effectiveness of COVID-19 Vaccines against the B.1.617.2 Variant [preprint bez daty], https:// khub.net/documents/135939561/430986542/Effectiveness + of +COVID-19+vaccines+against+the+B.1.617.2+variant.pdf/204c11a4-e02e-11f2-db19-b3664107ac42 (dostęp: 7.06.2021).

13. Carbonaro G., Vaccine Success vs Variants, Italy's Jabs Milestone: COVID-19 Bulletin, CGTN, May 23, 2021, https://newseu.cgtn.com/news/2021-05-23/Vaccine-success-vs-variants-Italy-s-jabs-milestone-COVID-19-Bulletin-10uYEQ7wXPa/index.html (dostęp: 3.06.2021).

14. Centers for Disease Control and Prevention, Benefits of Getting a COVID-19 Vaccine, April 12, 2021, https://www. cdc.gov/coronavirus/2019-ncov/vaccines/vaccine-benefits. html (dostęp: 8.06.2021).

15. Centers for Disease Control and Prevention, Hospitalized or Fatal COVID-19 Vaccine Breakthrough Cases Reported to CDC as of July 12, 2021, July 15, 2021, https://www. cdc.gov/vaccines/covid-19/health-departments/breakthrough-cases.html (dostęp: 17.07.2021).

16. Curley B., COVID-19 Vaccines Are More Than 90\% Effective: What That Means, Healthline, April 30, 2021, https:// www.healthline.com/health-news/covid-19-vaccines-aremore-than-90-effective-what-that-means (dostęp: 5.06.2021).

17. What are the Benefits of Getting the COVID-19 Vaccine?, Health Care, University of Missouri, 2020, https://www. muhealth.org/our-stories/what-are-benefits-getting-covid19-vaccine (dostęp: 7.06.2021).

18. Longman M., The COVID-19 Vaccines May Have Some Surprising Benefits, Refinery 29, April 7, 2021, https:// www.refinery29.com/en-us/vaccine-benefits-covid-pfizermoderna (dostęp: 4.06.2021).

19. Freeman D. et al., COVID-19 Vaccine Hesitancy in the UK: The Oxford Coronavirus Explanations, Attitudes, and Narratives Survey (Oceans) II, Psychological Medicine by Cambridge University Press, December 11, 2020, https:// www.cambridge.org/core/journals/psychological-medicine/ article/covid19-vaccine-hesitancy-in-the-uk-the-oxfordcoronavirus-explanations-attitudes-and-narratives-surveyoceans-ii/C30FDB5C3D87123F28E351FDAAD5351A (dostęp: 5.06.2021).

20. Di Gennaro F. et al., Attitudes towards Anti-SARS-CoV2 Vaccination among Healthcare Workers: Results from a $\mathrm{Na}$ tional Survey in Italy, „Viruses”, February 26, 2021, https:// pubmed.ncbi.nlm.nih.gov/33652829/(dostęp: 4.06.2021).
21. Coronavirus (COVID-19) Vaccinations. Willingness to Get Vaccinated against COVID, Our World in Data, April 30, 2021, https://ourworldindata.org/covid-vaccinations (dostęp: 3.06.2021).

22. Ćwiek J., Koronawirus. Sondaż: Więcej zaszczepionych wśród wyborców opozycji, Rzeczpospolita, 13.04.2021, https://www.rp.pl/Covid-19/304129935-Koronawirus-Sondaz-Wiecej-zaszczepionych-wsrod-wyborcow-opozycji. html (dostęp: 4.06.2021).

23. Dąbrowska Z., Ruszyły szczepienia. Duża część Polaków wciąż jednak sceptyczna, Rzeczpospolita, 27.12.2020, https://www.rp.pl/Covid-19/312279965-Ruszyly-szczepienia-Duza-czesc-Polakow-wciaz-jednak-sceptyczna.html (dostęp: 5.06.2021).

24. Apel naukowców i lekarzy w sprawie szczepień na koronawirusa SARS-CoV-2, Ordo Medicus, 30.11.2020, https://ordomedicus.org/apel-naukowcow-i-lekarzy-w-sprawie-szczepien-na-koronawirusa-sars-cov-2/ (dostęp: 4.06.2021).

25. Food and Drug Administration, Emergency Use Authorization for Vaccines Explained, November 20, 2020, https://www.fda. gov/vaccines-blood-biologics/vaccines/emergency-use-authorization-vaccines-explained (dostęp: 7.06.2021).

26. Food and Drug Administration, Pfizer-BioNTech COVID-19 Vaccine, May 19, 2021, https://www.fda.gov/emergencypreparedness-and-response/coronavirus-disease-2019-covid-19/pfizer-biontech-covid-19-vaccine (dostęp: 4.06.2021).

27. European Medicines Agency, EMA Recommends First COVID-19 Vaccine for Authorisation in the EU, December 21, 2020, https://www.ema.europa.eu/en/news/emarecommends-first-covid-19-vaccine-authorisation-eu (dostęp: 4.06.2021).

28. European Medicines Agency, COVID-19 Vaccine AstraZeneca: Benefits Still Outweigh the Risks Despite Possible Link to Rare Blood Clots with Low Blood Platelets, March 18, 2021, https://www.ema.europa.eu/en/news/covid-19-vaccine-astrazeneca-benefits-still-outweigh-risks-despite-possible-link-rare-blood-clots (dostęp: 7.06.2021).

29. World Health Organization, Coronavirus Disease (COVID-19): Herd Immunity, Lockdowns and COVID-19, December 31, 2020, https://www.who.int/news-room/q-adetail/herd-immunity-lockdowns-and-covid-19 (dostęp: 5.06.2021)

30. World Health Organization, WHO Director-General's Opening Remarks at the Media Briefing on COVID-19, October 12, 2020, https://www.who.int/director-general/ speeches/detail/who-director-general-s-opening-remarksat-the-media-briefing-on-covid-19---12-october-2020 (dostęp: 6.06.2021).

31. Petri W., Herd Immunity Appears Unlikely for COVID-19, but CDC Says Vaccinated People Can Ditch Masks in Most Settings, The Conversation, May 14, 2021, https://theconversation.com/herd-immunity-appears-unlikely-for-covid19-but-cdc-says-vaccinated-people-can-ditch-masks-inmost-settings-160228 (dostęp: 4.06.2021).

32. Hoge B., Five Benefits of Getting a COVID-19 Vaccine, The University of Alabama at Birmingham News, May 7, 2021, https://www.uab.edu/news/youcanuse/item/12025-fivebenefits-of-getting-a-covid-19-vaccine (dostęp: 6.06.2021).

33. J.W., Kardiolog: jest szansa, że odporność populacyjna pojawi się w Polsce we wrześniu, Rynek Zdrowia, 30 maja 
2021, https://www.rynekzdrowia.pl/Uslugi-medyczne/Kardiolog-jest-szansa-ze-odpornosc-populacyjna-pojawi-sie-w-Polsce-we-wrzesniu,222064,8.html (dostęp: 5.06.2021).

34. Gravagna K. et al., Global Assessment of National Mandatory Vaccination Policies and Consequences of NonCompliance, „Vaccine” 2020, vol. 38, no. 49, s. 78657873, https://www.sciencedirect.com/science/article/pii/ S0264410X20312342?via\%3Dihub (dostęp: 4.06.2021).

35. Robertson C., Paying People to Get Vaccinated Might WorkBut is it Ethical?, The Conversation, May 19, 2021, https:// theconversation.com/paying-people-to-get-vaccinated-mightwork-but-is-it-ethical-160959 (dostęp: 3.06.2021).

36. Dodd S., How to Get Promotions, Prizes and Freebies with your COVID-19 Vaccine, People, May, 18, 2021, https:// people.com/health/covid-19-vaccine-freebies-incentivesrewards/ (dostęp: 4.06.2021).

37. Krstic Z., All the COVID-19 Vaccine Card Free Treats and Discounts You Can Snag Now, Good Housekeeping, April 30, 2021, https://www.goodhousekeeping.com/life/ a36137436/covid-19-vaccine-card-free-deals-discounts/ (dostęp: 7.06.2021).

38. World Health Organization, COVID-19 and Mandatory Vaccination: Ethical Considerations and Caveats, April 13, 2021, https://www.who.int/publications/i/item/ WHO-2019-nCoV-Policy-brief-Mandatory-vaccination-2021.1 (dostęp: 7.06.2021).

39. World Health Organization, Interim Position Paper: Considerations Regarding Proof of COVID-19 Vaccination for International Travellers, 2021 (https://www.who.int/newsroom/articles-detail/interim-position-paper-considerationsregarding-proof-of-covid-19-vaccination-for-internationaltravellers). (dostęp: 4.06.2021).

40. Europejska Konwencja Praw Człowieka, Europejski Trybunał Praw Człowieka, https://echr.coe.int/Documents/ Convention_POL.pdf (dostęp: 6.06.2021).

41. Komunikat Komisji do Parlamentu Europejskiego, Rady i Europejskiego Banku Inwestycyjnego. Strategia UE dotycząca szczepionek przeciwko COVID-19, Bruksela, 17 czerwca 2020, https:/eur-lex.europa.eu/legal-content/ PL/TXT/PDF/?uri=CELEX:52020DC0245\&from=EN (dostęp: 8.06.2021).

42. Court's First Judgment on Compulsory Childhood Vaccination: No Violation of the Convention, The European Court of Human Rights, April 4, 2021, https://hudoc. echr.coe.int/app/conversion/pdf/?library $=$ ECHR\&id $=00$ 3-6989051-9414707\&filename $=$ Grand $\% 20$ Chamber $\% 20$ judgment $\% 20$ Vavricka $\% 20$ and $\% 20$ Others $\% 20$ v. $\% 20$ Czech\%20Republic\%20-\%20obligation\%20to\%20vaccinate $\% 20$ children $\% 20$ against $\% 20$ diseases $\% 20$ that $\% 20$ were $\% 20$ well $\% 20 \mathrm{known} \% 20$ to $\% 20$ medical $\% 20$ science. pdf (dostęp: 5.06.2021).

43. Liboreiro J., Pitchers Ch., How a Court Ruling Lays the gGound for Mandatory COVID-19 Vaccination, EuroNews, April 22/, 2021, https:/www.euronews.com/2021/04/13/ how-a-court-ruling-lays-the-ground-for-mandatory-covid19-vaccination (dostęp: 7.06.2021).

44. Can COVID-19 Vaccines Be Mandatory in the U.S. and Who Decides? School of Public Health Expert Insights. An Interview with Joanne Rosen, Johns Hopkins University Bloomberg School of Public Health, November 17, 2020, https://www.jhsph.edu/covid-19/articles/can-covid-19vaccines-be-mandatory-in-the-u-s-and-who-decides.html (dostęp: 4.06.2021)

45. National Health Service, England, Guidance to Support COVID-19 Vaccine Uptake in Frontline Staff, March 12, 2021, https:/www.england.nhs.uk/coronavirus/wp-content/uploads/ sites/52/2021/03/C1195-guidance-on-supporting-covid-19vaccine-uptakey,-in-staff-v2.pdf (dostęp: 4.06.2021).

46. Wise J., COVID-19: Is the UK Heading Towards Mandatory Vaccination of Healthcare Workers?, BMJ, 2021; https:// www.bmj.com/content/373/bmj.n1056 (dostęp: 6.06.2021).

47. Giubilini A., Jain V., Should COVID-19 Vaccines Be Mandatory? Two Experts Discuss, The Conversation. November 25, 2020, https://theconversation.com/should-covid19-vaccines-be-mandatory-two-experts-discuss- 150322 (dostęp: 4.06.2021).

48. Broughton C., Covid-19 Vaccine Should be Mandatory for Health Workers, Expert Says, Stuff, May 8, 2021, https:// www.stuff.co.nz/national/health/coronavirus/125035281/ covid19-vaccine-should-be-mandatory-for-health-workers-expert-says (dostęp: 3.06.2021).

49. Paterlini M., COVID-19: Italy Makes Vaccination Mandatory for Healthcare Workers, BMJ, 2021, https://www.bmj. com/content $/ 373 /$ bmj.n905? ijkey $=400 \mathrm{c} 5 \mathrm{~cd} 61 \mathrm{~d} 426585 \mathrm{e}-$ 0b86546e9b53f35461a9341\&keytype $2=$ tf_ipsecsha (dostęp: 5.06.2021).

50. Centers for Disease Control and Prevention, COVID-19 Vaccination for Essential Workers, May 25, 2021, https:// www.cdc.gov/coronavirus/2019-ncov/vaccines/recommendations/essentialworker.html (dostęp: 7.06.2021). 